\title{
Ankylosing spondylitis, HLA-B27, and klebsiella: a study of lymphocyte reactivity of anti-klebsiella sera*
}

\author{
B SINGH, J D MILTON, AND J C WOODROW
}

From the University Department of Medicine, Royal Liverpool Hospital, PO Box 147, Liverpool L69 3BX $\vec{\circ}$

SUMmaRY Twenty three anti-klebsiella antisera were tested for their cytotoxic activity and four for their binding capacity for peripheral blood lymphocytes (PBL) from patients with HLA-B27 positive ankylosing spondylitis $\left(\mathrm{AS}^{+} \mathrm{B} 27^{+}\right)$and from $\mathrm{B} 27$ positive $\left(\mathrm{AS}{ }^{-} \mathrm{B} 27^{+}\right)$and $\mathrm{B} 27$ negative $e_{\omega}^{\mathrm{C}}$ $\left(\mathrm{AS}^{-} \mathrm{B}^{-} 7^{-}\right)$healthy individuals. None of the antisera showed specific activity against PBL from $\vec{\bullet}$ any particular group. The antisera tested included two anti-klebsiella K43 sera provided by anO Australian group, who have reported them to be specifically cytotoxic for $\mathrm{AS}^{+} \mathrm{B} 27^{+} \mathrm{PBL}$, four응 antisera raised against a klebsiella $\mathrm{K} 43$ strain provided by this group, and an antiserum from ${ }_{-}^{-}$ another group, who have reported it as having increased binding capacity for $\mathrm{AS}^{+} \mathrm{B} 27^{+}$and $\mathrm{AS}^{-} \mathrm{B} 27^{+} \mathrm{PBL}$ compared with $\mathrm{AS}^{-} \mathrm{B} 27^{-} \mathrm{PBL}$. The results of other workers who have attempted产 to reproduce the results of either group are reviewed and the possible reasons for the repeated $\vec{\bullet}$ failure to confirm the reported findings are discussed.

Of the numerous associations between diseases and particular HLA antigens, perhaps the most striking is that between ankylosing spondylitis (AS) and HLA-B27. ${ }^{1}$ The increased frequency of B27 in other seronegative arthropathies such as Reiter's disease, ${ }^{2}$ and reactive arthritis after gastrointestinal infection with shigella, ${ }^{34}$ salmonella, ${ }^{56}$ or yersinia ${ }^{5}$ is also well established. The association of B27 with these diseases could be either because B27 is directly involved in disease susceptibility or because there is linkage disequilibrium between the B27 gene and a disease susceptibility gene. ${ }^{7}$

It has been suggested by two different groups of workers that Klebsiella pneumoniae may have a role in the pathogenesis of AS in B27 positive individuals. Ebringer and his colleagues have based this suggestion partly on their finding that anti-klebsiella serum binds more strongly to $\mathrm{PBL}$ from $\mathrm{AS}^{+} \mathrm{B} 27^{+}$ and $\mathrm{AS}^{-} \mathrm{B} 27^{+}$subjects compared with $\mathrm{AS}^{-} \mathrm{B} 27^{-}$ PBL in enzyme linked immunosorbent assays (ELISA). ${ }^{8}$ This, together with other evidence, ${ }^{9-11}$ has been interpreted by Ebringer ${ }^{8}$ as providing evidence for the 'cross tolerance' hypothesis for the pathogenesis of AS, klebsiella infection giving rise

Accepted for publication 29 July 1985.

Correspondence to Dr B Singh, Wolfson Tropical Immunology Unit, Liverpool School of Tropical Medicine, Pembroke Place, Liverpool L3 5QA.

*Comments on this paper appear in the 'Correspondence' section of this issuc. to antibodies, which are then capable of cross reacting with the B27 antigen on certain tissues.

On the other hand, Geczy and his coworkers in Australia have used a complement dependent $\stackrel{\circ}{\longrightarrow}$ chromium release cytotoxic assay and found thato certain anti-klebsiella sera are cytotoxic for $\mathrm{PBL}^{\exists}$ from the majority of $\mathrm{AS}^{+} \mathrm{B} 27^{+}$individuals, but not for cells from $\mathrm{AS}^{-} \mathrm{B} 27^{+}$individuals, even when they are first degree relatives of AS patients. ${ }^{12-14}$ They have interpreted this work, together with sub-sequent studies, ${ }^{15} 16$ as suggesting that there is present on the surface of nucleated cells of $\mathrm{AS}^{+} \mathrm{B} 27^{+}$individuals a component of the cell wall of certain klebsiella strains which is in close associationo with the B27 antigen.

It is apparent that there is a fundamental diver gence between the experimental findings of these two groups of workers. This study is concerned withos trying to confirm the results of either group with anti-klebsiella sera and by three techniques: chro-n mium release cytotoxicity assays, dye exclusiong microcytotoxicity assays, and ELISA.

\section{Patients and methods}

PATIENTS AND CONTROLS All patients were diagnosed as having AS according to the New York criteria. ${ }^{17}$ The healthy controls were members of staff and students with no presenf or previous history of joint disease. All patients anok 
controls were tissue typed by a two stage microlymphocytotoxicity assay. ${ }^{18}$

\section{BACTERIAL CULTURES}

Bacteria were grown in tryptone soya broth (TSB; Oxoid) and killed by adding $0.25 \mathrm{ml}$ of $40 \%$ formaldehyde to a $20 \mathrm{ml}$ suspension of the organisms $\left(10^{9}-10^{10} / \mathrm{ml}\right)$ in TSB. The formalin killed bacteria were washed twice with sterile $0.9 \% \mathrm{NaCl}$ and stored at $-20^{\circ} \mathrm{C}$.

\section{A N T I S E R A}

Antisera were raised in New Zealand white rabbits and $\mathrm{BALB} / \mathrm{c}$ mice against 13 local klebsiella isolates and a klebsiella K43 isolate from Dr A F Geczy of the New South Wales Red Cross Blood Transfusion Service, Sydney, Australia.

Rabbits (3-5 kg) were immunised with formalin killed bacterial suspensions according to the method of Seager et al. ${ }^{12}$ Briefly, the animals were each injected intravenously with approximately $10^{9}$ bacteria in $2 \mathrm{ml} 0.9 \% \mathrm{NaCl}$ and two weeks later intramuscularly with approximately $10^{10}$ bacteria in $2 \mathrm{ml}$ Freund's complete adjuvant (Difco). Ten days later the rabbits were boosted intravenously with 1 $\mathrm{ml}$ of bacterial suspension $\left(10^{8}-10^{9}\right.$ organisms) in $0.9 \% \mathrm{NaCl}$ and two weeks after this the rabbits were bled and the serum stored at $-40^{\circ} \mathrm{C}$.

Mice in groups of 10-15 were each injected intraperitoneally with $0.1 \mathrm{ml}$ of bacterial inoculum $\left(10^{9}-10^{10}\right.$ organisms $\left./ \mathrm{ml} 0.9 \% \mathrm{NaCl}\right)$ and were then boosted intraperitoneally on two occasions at weekly intervals with $0.1 \mathrm{ml}$ of bacterial inoculum. Two weeks after the last injection the mice were bled and the serum was pooled and stored at $-20^{\circ} \mathrm{C}$.

Each antiserum was tested against concentrated bacterial culture supernatants of various strains of klebsiella by the double diffusion technique. ${ }^{19}$ Precipitin lines were observed for all antisera against homologous culture supernatants and in some cases against heterologous culture supernatants.

Antisera were also obtained from Dr A Ebringer of the Department of Rheumatology, Middlesex Hospital, London and from Dr A F Geczy.

CHROMIUM RELEASE LYMPHOCYTOTOXICITY A S S A Y

Peripheral blood lymphocytes were obtained from defibrinated blood by centrifugation in Ficoll-Paque (Pharmacia Ltd). They were washed three times in Hanks's balanced salt solution (HBSS; Wellcome) containing $0.035 \%$ sodium bicarbonate. $10 \times 10^{6}$ PBL were resuspended in $1 \mathrm{ml}$ of HBSS supplemented with $10 \%$ decomplemented newborn calf serum (NBCS; Flow Laboratories Ltd) and were incubated with $100 \mu \mathrm{Ci}^{51} \mathrm{Cr}$ (Amersham) for $60 \mathrm{~min}$ at $37^{\circ} \mathrm{C}$. After washing three times with complement fixation test diluent (CFT; Flow) containing 2\% NBCS (CFT/NBCS) the cells were suspended at a concentration of $1 \times 10^{6} \mathrm{PBL} / \mathrm{ml}$. Ten serial doubling dilutions of each test serum were prepared with CFT/NBCS and $100 \mu \mathrm{l}$ of the ${ }^{51} \mathrm{Cr}$ labelled PBL suspension was added to $100 \mu \mathrm{l}$ of each serum dilution. This was followed by the addition of $100 \mu \mathrm{l}$ of rabbit complement (Buxted Rabbit Co, Sussex) which had been diluted 1:5 with CFT/NBCS. After one hour at $37^{\circ} \mathrm{C} 1.5 \mathrm{ml}$ of cold $0.9 \% \mathrm{NaCl}$ was added to each tube and after centrifugation the supernatants were removed for radioactivity measurements in a gammacounter (LKB Instruments).

The amount of radioactivity in the samples was compared with the radioactivity present in the supernatants from tubes containing PBL in medium plus complement only, and with that present in tubes containing cells which had been lysed by the addition of $200 \mu \mathrm{l}$ of $0.1 \%$ Triton-X 100 . The results are expressed as the percentage of maximum ${ }^{51} \mathrm{Cr}$ released at any serum dilution:

Percentage ${ }^{51} \mathrm{Cr}$ release $=\frac{\begin{array}{l}\text { Radioactivity } \\ \text { released by } \\ \text { antiserum }\end{array}}{\begin{array}{l}\text { Radioactivity } \\ \text { released by } \\ \text { Triton-X }\end{array}} \begin{aligned} & \begin{array}{l}\text { Radioactivity } \\ \text { released in } \\ \text { absence of } \\ \text { antiserum }\end{array} \\ & \begin{array}{l}\text { Radioactivity } \\ \text { released in } \\ \text { absence of } \\ \text { antiserum }\end{array}\end{aligned} \times 100$

Rabbit antihuman lymphocyte antiserum (ALS) was used as a positive control in all the lymphocytotoxicity assays, and maximum levels of cytotoxicity ranged from 75 to $95 \%$ chromium release.

\section{DYE EXCLUSION}

MICROLYMPHOCYTOTOXICITY ASSAY

Five serial doubling dilutions of serum were prepared in CFT and $0.5 \mu \mathrm{l}$ pipetted into wells under liquid paraffin. $0.5 \mu \mathrm{l}$ of PBL at a concentration of $10^{7} \mathrm{cells} / \mathrm{ml}$ was incubated with each serum dilution for $30 \mathrm{~min}$ at $20^{\circ} \mathrm{C}$ followed by the addition of $2.5 \mu \mathrm{l}$ of rabbit complement and incubation for a further $60 \mathrm{~min}$. Cells were stained with $1 \mu \mathrm{l}$ of $0.25 \%$ trypan blue after excess complement and serum had been removed with a peristaltic pump, and viability was assessed by examination under an inverted microscope.

ALS and human anti-B27 tissue typing sera were used as controls in all the assays. Cell death greater than $50 \%$ was taken as a definite positive result and ALS was positive for all the PBL tested at all the five serum dilutions, while the B27 tissue typing sera were positive for at least the first three serum 
dilutions for PBL from the B27 positive patients and controls.

\section{E L I S A}

The assays were carried out with rigid flat bottomed, 96 well microELISA plates (Dynatech) which had been coated with $0.1 \mathrm{mg} / \mathrm{ml}$ poly-L-lysine by incubation at $37^{\circ} \mathrm{C}$ for one hour. The plates were washed three times with phosphate buffered saline (PBS) and $100 \mu \mathrm{l}$ samples of PBL at a concentration of $5 \times 10^{6}$ cells $/ \mathrm{ml}$ were incubated in appropriate wells for one hour at $37^{\circ} \mathrm{C}$ after centrifugation of the plates at $100 \mathrm{~g}$ for five minutes to sediment the cells. The wells were washed three times with PBS and incubated with $100 \mu \mathrm{l} 0.3 \%$ gelatine in PBS (PBS$\mathrm{Gel})$ to saturate any remaining protein reactive sites. After three washes with PBS $100 \mu \mathrm{l}$ samples of four rabbit anti-klebsiella sera diluted 1:500 with PBS-Gel and each of five dilutions of ALS (1:300, $1: 1000,1: 3000,1: 10000$, and 1:30 000) were added to the appropriate wells. After incubation at $37^{\circ} \mathrm{C}$ for one hour the wells were washed three times with PBS and then $100 \mu$ l of horseradish peroxidase labelled, swine antirabbit immunoglobulins (Mercia Brocades Ltd) diluted 1:1000 with PBS-Gel was added to each well. The plates were incubated and washed as described previously and $100 \mu \mathrm{l}$ of fresh substrate solution was added to each well. The substrate solution was prepared by dissolving $10 \mathrm{mg}$ of $o$-phenylenediamine in $25 \mathrm{ml}$ of phosphate citrate buffer (pH 5.0; 9.15. $\mathrm{g}$ disodium hydrogen $\frac{\mathrm{D}}{\mathrm{N}}$ orthophosphate dihydrate and $5 \cdot 11 \mathrm{~g}$ citric acid $\Rightarrow$

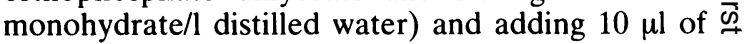
hydrogen peroxide immediately before use. The substrate was allowed to react with the contents of the wells for five minutes at room temperature before the reaction was stopped by the addition of $\mathbb{Q}$ $100 \mu \mathrm{l} 4 \mathrm{M} \mathrm{H}_{2} \mathrm{SO}_{4}$. The optical density (OD) was determined at a wavelength of $492 \mathrm{~nm}$ by a vertical $\vec{\circ}$ light spectrophotometer (Titertek Multiscan, Flow Laboratories Ltd).

The tests were all carried out in duplicate wells and the corrected OD for each test sample was calculated by subtracting the mean OD of the control with the highest value (i.e., wells with PBL, enzyme-antibody conjugate, and substrate but no serum) from that of the test sample. A standard curve was plotted for each PBL suspension from 응 measurements on five dilutions of ALS and the binding capacity of each anti-klebsiella serum for a $\vec{z}$ particular PBL suspension was calculated from this standard curve: a serum which produced an OD that corresponded with an ALS dilution of 1:500 was $\overrightarrow{0}$ assigned a binding capacity of 100 units and one which corresponded with a dilution of 1:5000 a binding capacity of 10 units.

STATISTICAL ANALYSIS

The results of the lymphocytotoxicity assays and the ELISAs were analysed by the Mann-Whitney $U$

Table 1 Lymphocytotoxic activity of antisera raised against local isolates

\begin{tabular}{|c|c|c|c|c|c|c|}
\hline \multirow{2}{*}{$\begin{array}{l}\text { Serum } \\
\text { No }\end{array}$} & \multirow[t]{2}{*}{ Source } & \multirow{2}{*}{$\begin{array}{l}\text { Capsular } \\
\text { serotype }\end{array}$} & \multirow{2}{*}{$\begin{array}{l}\text { Animal } \\
\text { immunised }\end{array}$} & \multicolumn{3}{|c|}{ No $>25 \%{ }^{5 /} \mathrm{Cr}$ release/No testedt } \\
\hline & & & & $A S^{+} B 27^{+}$ & $A S^{-} B 27^{-}$ & $A S^{-} B 27^{+}$ \\
\hline AK6 & RI & K39 & Rabbit & $1 / 18$ & $0 / 8$ & $0 / 8$ \\
\hline AK11 & RI & K46 & Rabbit & $0 / 14$ & $0 / 8$ & $0 / 1$ \\
\hline AK12 & RI & $\mathbf{K} 2$ & Rabbit & $0 / 14$ & $0 / 8$ & $0 / 4$ \\
\hline AK16 & RI & $\mathrm{NT} \ddagger$ & Rabbit & $4 / 30$ & $0 / 15$ & $0 / 8$ \\
\hline AK23 & RI & K68 & Mouse & $0 / 10$ & $0 / 8$ & $0 / 1$ \\
\hline AK26 & RI & K43 & Rabbit & $2 / 24$ & $0 / 14$ & $0 / 5$ \\
\hline AK41 & $\mathrm{AS} \ddagger$ & K41 & Mouse & $0 / 6$ & $0 / 1$ & $0 / 3$ \\
\hline AK42* & RI & $\mathrm{K} 21$ & Mouse & $11 / 11$ & $5 / 6$ & $3 / 3$ \\
\hline AK43 & AS & K52 & Mouse & $0 / 6$ & $0 / 1$ & $0 / 1$ \\
\hline AK44 & AS & K29 & Mouse & $0 / 6$ & $0 / 1$ & $0 / 3$ \\
\hline AK45 & RI & $\mathrm{K} 43$ & Mouse & $0 / 6$ & $0 / 1$ & $0 / 3$ \\
\hline AK46 & RI & K43 & Mouse & $0 / 6$ & $0 / 1$ & $0 / 3$ \\
\hline AK47 & RI & K43 & Mouse & $0 / 6$ & $0 / 1$ & $0 / 3$ \\
\hline AK48* & RI & K21 & Mouse & $0 / 12$ & $0 / 4$ & $0 / 2$ \\
\hline AK49* & RI & K21 & Rabbit & $0 / 16$ & $0 / 13$ & $0 / 2$ \\
\hline AK $50^{*}$ & RI & K21 & Rabbit & $0 / 16$ & $0 / 11$ & $0 / 2$ \\
\hline
\end{tabular}

Sera were raised in Liverpool against local klebsiella isolates and tested against PBL by the chromium release assay described in 'Patients and methods'.

*Four antisera prepared with the same klebsiella K21 isolate.

+ Number of PBL suspensions that each gave greater than $25 \%$ chromium release out of a total that were tested for each group of $\mathrm{AS}^{-}$and $\mathrm{AS}^{+}$individuals as described in 'Patients and methods'.

$\ddagger R I=$ random klebsiella isolates; $A S=$ klebsiella strains isolated from the faeces of $A S$ patients; NT=non-typable. 
test, which is the non-parametric equivalent of the $t$ test. $^{20}$

\section{Results}

LYM PHOCYTOTOXIC ACTIVITY OF

A N T I - K L E B S I E L L A S ERA

Determination by a chromium release cytotoxicity assay

Antisera were raised against 13 local klebsiella strains, three of which were isolated from the faeces of three AS patients. Levels of cytotoxicity rarely exceeded $25 \%$ chromium release when these antisera were tested against PBL from $\mathrm{AS}^{+} \mathrm{B} 27^{+}$ patients, $\mathrm{AS}^{-} \mathrm{B} 27^{-}$individuals, and $\mathrm{AS}^{-} \mathrm{B} 27^{+}$ individuals (Table 1). The exception was antiserum AK42, an anti-klebsiella K21 serum raised in mice, which was cytotoxic for PBL from all the groups tested. A typical example of the cytotoxic pattern obtained with this antiserum is shown in Fig. 1. When a further group of mice and two rabbits were immunised with this klebsiella $\mathrm{K} 21$ isolate the resultant antisera (AK48, AK49, and AK50) failed to show similar lymphocytotoxic activity (Table 1 ).
By comparing the distribution of percentage chromium release produced by the various antisera in the $\mathrm{AS}^{+} \mathrm{B} 27^{+}$group with that of the two control groups using the Mann-Whitney test, no statistically significant difference was found.

Antisera raised in Liverpool against the 'cross reactive' klebsiella K43 isolate provided by Geczy were tested together with antisera from Geczy and Ebringer. Chromium release exceeded $25 \%$ for PBL from only one $\mathrm{AS}^{+} \mathrm{B} 27^{+}$patient out of a total of $21 \mathrm{AS}^{+} \mathrm{B} 27^{+}$patients, $18 \mathrm{AS}^{-} \mathrm{B} 27^{-}$, and two $\mathrm{AS}^{-} \mathrm{B} 27^{+}$individuals tested (Table 2). In these tests postimmunisation sera rarely showed greater lymphocytotoxic activity than that of the corresponding preimmunisation sera (Fig. 2). Statistical analysis of the data again showed no significant difference between the distribution of chromium release in patients compared with that in controls.

Determination by a dye exclusion microlymphocytotoxicity assay

As shown in Table 3 the results of these assays confirmed those of the chromium release lym-

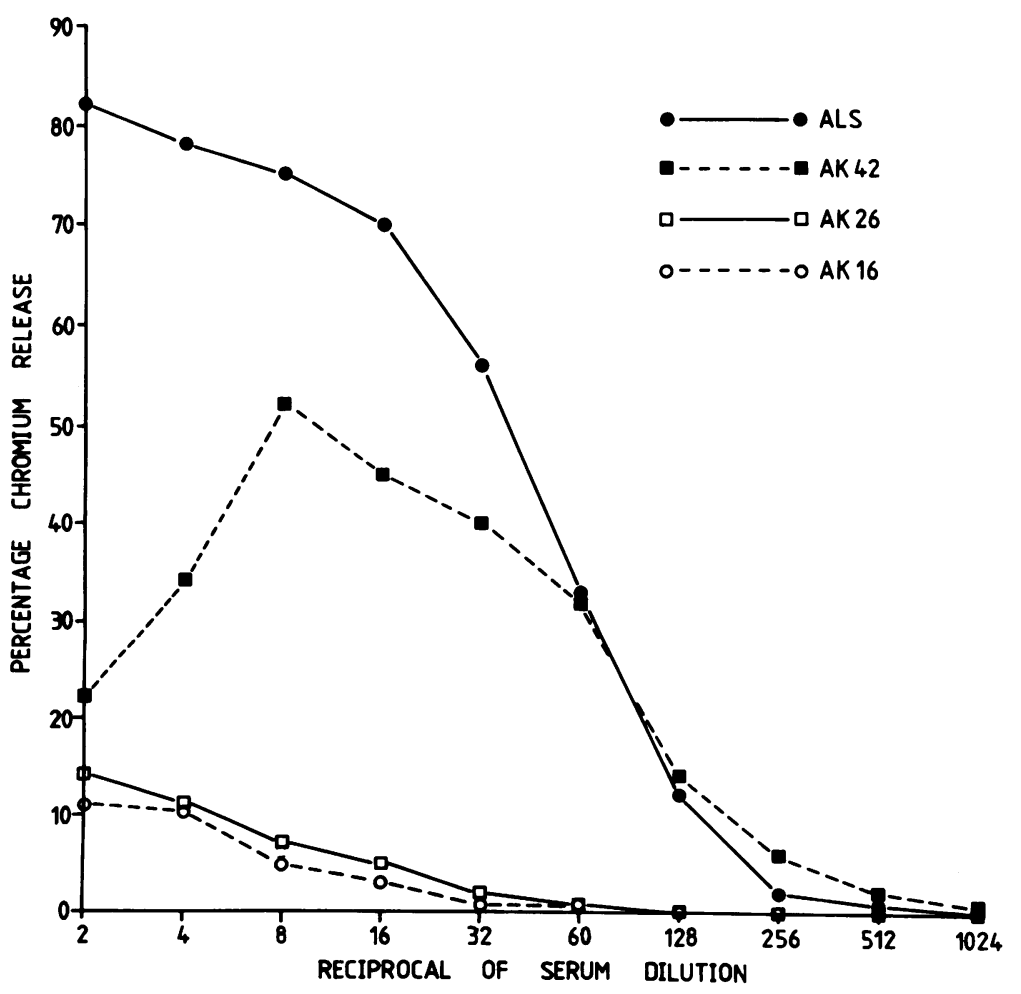

Fig. 1 Lymphocytotoxicity pattern obtained when testing $P B L$ from an $A S^{-} B 27^{-}$individual. Lymphocytotoxicity of the various antisera was tested as described in 'Patients and methods'. Details of the antisera are given in Table 1. 
Table 2 Lymphocytotoxic activity of antisera against the 'cross reactive' klebsiella isolates

\begin{tabular}{llll}
\hline $\begin{array}{l}\text { Serum } \\
\text { code }\end{array}$ & \multicolumn{2}{l}{ No $>25 \%{ }^{5 /} \mathrm{Cr}$ release/No tested } \\
\cline { 2 - 4 } & $A S^{+} B 27^{+}$ & $A S^{-} B 27^{-}$ & $A S^{-} B 27^{+}$ \\
\hline EAK & $0 / 21$ & $0 / 4$ & $0 / 2$ \\
GAK & $0 / 8$ & - & $0 / 2$ \\
FGAK & $1 / 10$ & $0 / 4$ & - \\
AK51 & $1 / 15$ & $0 / 18$ & $0 / 2$ \\
AK52 & $1 / 17$ & $0 / 18$ & $0 / 2$ \\
AK57 & $1 / 14$ & $0 / 18$ & $0 / 2$ \\
AK60 & $1 / 14$ & $0 / 18$ & $0 / 2$ \\
\hline
\end{tabular}

Sera were tested against PBL by the chromium release assay described in 'Patients and methods'.

${ }^{*} \mathrm{EAK}=$ anti-klebsiella antiserum from Ebringer; GAK=antiklebsiella K43 serum from Geczy; FGAK=reconstituted freeze dried GAK from Geczy; AK51, 52, 57, and 60=antisera raised in Liverpool against the 'cross reactive' klebsiella $\mathrm{K} 43$ isolate from Geczy

†Number of PBL suspensions that each gave greater than $25 \%$ chromium release out of a total that were tested for each group of $\mathrm{AS}^{-}$and $\mathrm{AS}^{+}$individuals as described in 'Patients and methods'.

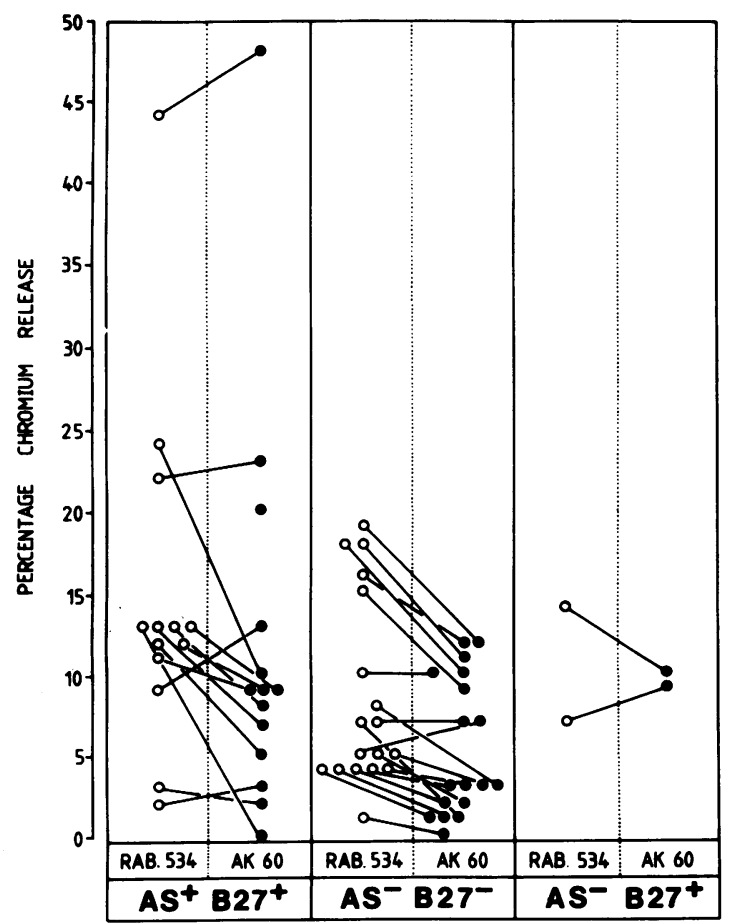

Fig. 2 Lymphocytotoxic activity of preimmunisation and postimmunisation sera. Rabbit No 534 was immunised with the Australian klebsiella K43 isolate to produce antiserum $A K 60$ and both the sera were tested for lymphocytotoxicity against $P B L$ from $14 \mathrm{AS}^{+} B 27^{+}, 18 \mathrm{AS}^{-} \mathrm{B27} 7^{-}$, and two $A S B 27^{+}$individuals by the chromium release assay described in 'Patients and methods'.
Table 3 Lymphocytotoxic activity of antisera determined by microlymphocytotoxicity assays

\begin{tabular}{llcl}
\hline $\begin{array}{l}\text { Serum } \\
\text { code* }\end{array}$ & \multicolumn{3}{l}{ No $>50 \%$ cell killing/No tested } \\
\cline { 2 - 4 } & $A S^{+} B 27^{+}$ & $A S^{-} B 27^{-}$ & $A S^{-} B 27^{+}$ \\
\hline AK42 & $20 / 20$ & $14 / 14$ & $2 / 2$ \\
AK43 & $4 / 20$ & $3 / 14$ & $1 / 2$ \\
AK44 & $2 / 20$ & $2 / 14$ & $0 / 2$ \\
AK50 & $0 / 20$ & $0 / 14$ & $0 / 2$ \\
RAB534 & $0 / 20$ & $0 / 14$ & $0 / 2$ \\
AK60 & $0 / 20$ & $0 / 14$ & $0 / 2$ \\
FGAK & $0 / 20$ & $0 / 14$ & $0 / 2$ \\
A-B27 & $20 / 20$ & $0 / 14$ & $2 / 2$ \\
ALS & $20 / 20$ & $14 / 14$ & $2 / 2$
\end{tabular}

*A-B27 = human anti-HLA-B27 tissue typing serum. For other sera or refer to legends to Fig. 2 and Tables 1 and 2 .

†Number of PBL suspensions that each gave greater than $50 \%$ cell $\overrightarrow{0}$ killing out of a total that were tested for each group of $\mathrm{AS}^{-}$and $\mathrm{AS}^{+}$individuals as described in 'Patients and methods'.

phocytotoxicity assays in that antiserum AK42 was the only anti-klebsiella serum that was cytotoxic, and that its cytotoxic activity was directed against all the PBL samples tested.

BINDING CAPACITY OF ANTI-KLEBSIELLA SERA FOR PBL

The results of the ELISAs to determine the binding capacity of anti-klebsiella sera for PBL are shown in Fig. 3. There was no statistically significant difference in the binding capacity for $\mathrm{AS}^{+} \mathrm{B} 27^{+} \mathrm{PBL}$ compared with $\mathrm{AS}^{-} \mathrm{B} 27^{-} \mathrm{PBL}$ for any of the antisera, indicating that each antiserum bound equally well to both groups of PBL.

\section{Discussion}

There is good evidence for the participation of 을 HLA linked genes in the pathogenesis of many chronic disorders, but in no case has the mechanism of the action of such genes been as yet elucidated. Thus the evidence provided by Geczy and his $\sigma$ colleagues, ${ }^{16}$ and Ebringer and coworkers,${ }^{8}$ for the $N$ involvement of klebsiella in AS is of major N importance. The difficulty has been that no other $O$ group of workers has been able to reproduce either set of experimental findings, namely the cross reaction of klebsiella and B27 or tiie presence on $\stackrel{\mathcal{D}}{\rightarrow}$ $\mathrm{AS}^{+} \mathrm{B} 27^{+}$cells of a klebsiella derived component.

Archer, with a ${ }^{51} \mathrm{Cr}$ release assay, tested eight 0 anti-klebsiella sera, including two provided by $\overrightarrow{\mathbb{D}}$ Ebringer, against PBL from both $\mathrm{B} 27^{-}$and $\mathrm{B} 27^{+} \AA$ individuals, the latter including both $\mathrm{AS}^{-}$and $\mathrm{AS}^{+}$ subjects. $^{21}$ There was no significant cytotoxicity 


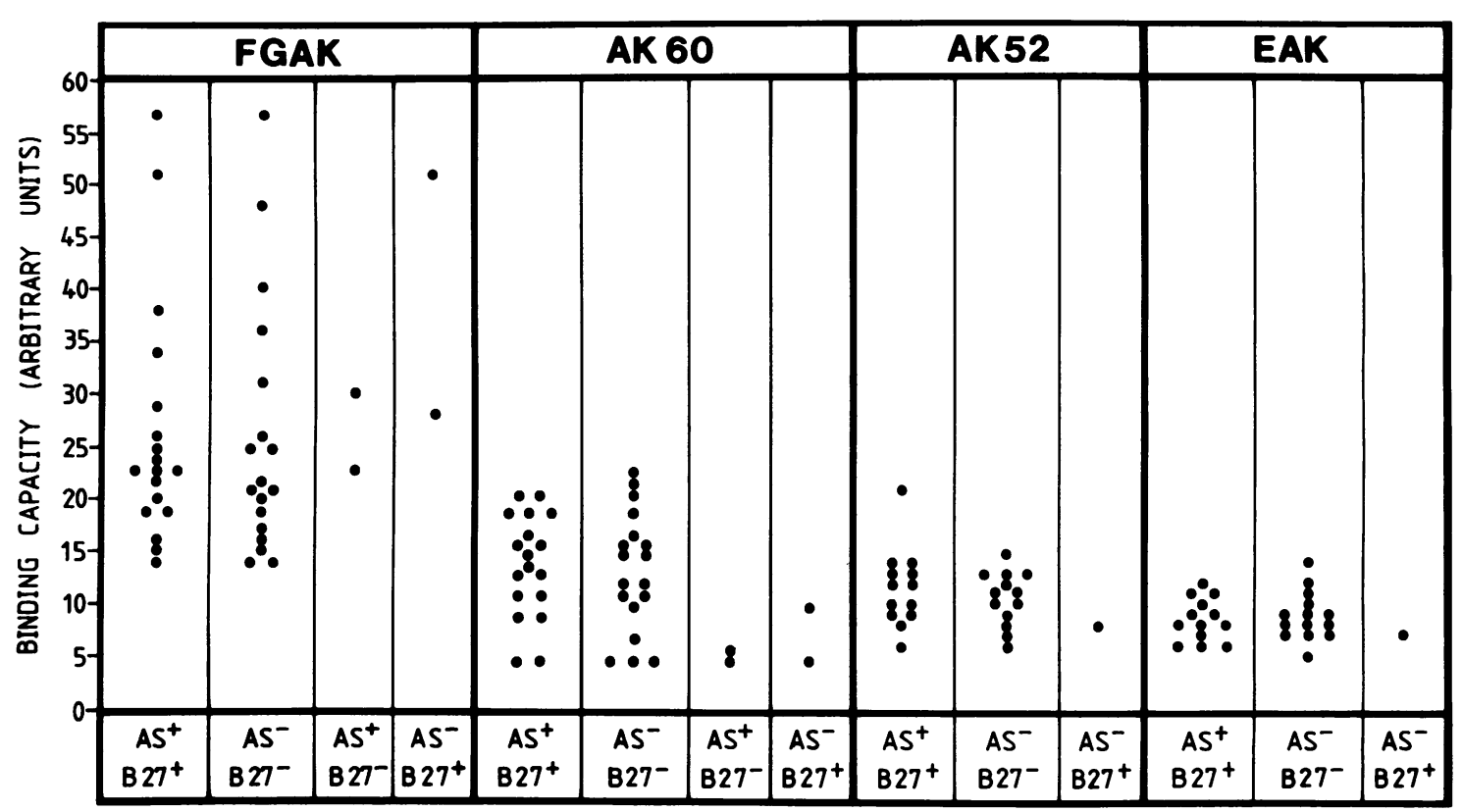

Fig. 3 Binding capacity of anti-klebsiella sera for $P B L$ from $A S$ patients and controls. The antisera were tested by an ELISA as described in 'Patients and methods' against $P B L$ from a maximum of $18 \mathrm{AS}^{+} B 27^{+}, 18 \mathrm{AS} \mathrm{S}^{-} \mathrm{B27^{- }}$, two $A S^{+} B 27^{-}$, and two $A S^{-} B 27^{+}$individuals. Details of the antisera are given in Table 2.

against the cells of either group. Shinebaum and coworkers, with the same cytotoxicity assay, tested up to 49 sera which had been raised to detect klebsiella serotypes, against PBL from $10 \mathrm{AS}^{+} \mathrm{B} 27^{+}$ and eight $\mathrm{AS}^{-} \mathrm{B} 27^{-}$individuals. 22 Eleven were found to be cytotoxic but only against PBL from one AS patient. Kinsella and colleagues have used both ${ }^{51} \mathrm{Cr}$ release and dye exclusion microcytotoxicity assays to test sera raised against four local klebsiella isolates (personal communication). ${ }^{23} 24$ They too have found that none of their antisera has greater lymphocytotoxic activity for $\mathrm{AS}^{+} \mathrm{B} 27^{+} \mathrm{PBL}$ compared with $\mathrm{AS}^{-} \mathrm{B} 27^{-}$or $\mathrm{AS}^{-} \mathrm{B} 27^{+} \mathrm{PBL}$. Recently Beaulieu and coworkers, again with a ${ }^{51} \mathrm{Cr}$ release assay, tested 98 different anti-klebsiella sera, four of which had been raised against organisms isolated from patients with AS and two of which were against organisms provided by Geczy. ${ }^{25}$ Again none of the sera was found to show significant cytotoxicity, all of them producing less than $15 \%{ }^{51} \mathrm{Cr}$ release.

In the investigation reported here only one of 23 anti-klebsiella sera showed greater than $25 \%{ }^{51} \mathrm{Cr}$ release with all $\mathrm{AS}^{+} \mathrm{B} 27^{+} \mathrm{PBL}$ samples. However, this particular anti-K21 serum also reacted with $\mathrm{AS}^{-} \mathrm{B} 27^{+}$and $\mathrm{AS}^{-} \mathrm{B} 27^{-} \mathrm{PBL}$, and three further antisera raised against the same $\mathrm{K} 21$ isolate failed to show cytoxicity against any of these cells. Four antisera raised against a K43 strain supplied by Geczy and antisera provided by Geczy and Ebringer failed to show activity against $\mathrm{AS}^{+} \mathrm{B} 27^{+}$lymphocytes.

The repeated failure in several laboratories to confirm the original findings has not been satisfactorily explained. There is considerable antigenic variability between different strains of klebsiella, some 80 different capsular serotypes being known. ${ }^{26}$ Gezcy and Yap reported that $8 \%$ of randomly selected klebsiella isolates are capable of absorbing the activity of a particular anti-klebsiella serum cytotoxic for PBL from $\mathrm{AS}^{+} \mathrm{B} 27^{+}$individuals and that there was no inter-relationship between this 'cross reactivity' and the capsular serotypes. ${ }^{27}$ It is apparent, however, that a considerable number of different isolates of klebsiella, including some supplied by Ebringer and by Geczy, have now been tested and no antisera have been produced with the originally described specificity. ${ }^{21-25}$ It seems therefore unlikely that different strains of organism used by different groups could be responsible for the discrepancy. A further source of discrepancy could result from the variation between experimental animals used in the different studies. A large 
number of rabbits, however, have now been used in the various reported studies without this resulting in antibodies with the specificity sought. Furthermore, antisera provided by Geczy have also failed to show specific lymphocytotoxicity for $\mathrm{AS}^{+} \mathrm{B} 27^{+} \mathrm{PBL}$. In regard to the assays used a puzzling feature is that the specific cytotoxicity of certain anti-klebsiella sera could only be shown by the ${ }^{51} \mathrm{Cr}$ release method and not by an immunofluorescence or a dye exclusion cytotoxicity assay. ${ }^{28}$ In the present study although the ${ }^{51} \mathrm{Cr}$ release method differs from that used by Seager et al, ${ }^{12}$ high levels of cytotoxicity were obtained against the lymphocytes in control tests with antilymphocytic serum, and also in dye exclusion microlymphocytotoxicity assays with antiB27 alloantisera. A notable feature in the data reported by Geczy and his colleagues is that the level of cytotoxicity by ${ }^{51} \mathrm{Cr}$ release assays was consistently lower for anti-B27 alloantisera, i.e., 41, 44 , and $65 \%$, than that observed for the antiklebsiella sera, i.e., 74, 69, and $80 \% .^{12} 1529$ Yet when dye exclusion methods were used, which might be expected to give approximately $100 \%$ cytotoxicity for isoantibodies, negative results were apparently obtained when anti-klebsiella sera were tested. Comparison of the methods used in different laboratories suggests that it is doubtful that variation in the source of the complement used in the cytotoxicity assays could be important, or that the final concentration of complement matters, as it has been shown that the lymphocytotoxic effect is apparent at a lower complement concentration. ${ }^{30}$ The investigations reported here also include a series of experiments in which assays independent of complement (ELISA) were used, and the results again were negative.

In conclusion, we, like others, including Georgopoulos $e t a l^{31}$ have failed to find evidence that antisera raised against klebsiella organisms have any particular ability to react with $\mathrm{B}_{2} 7^{+}$lymphocytes, and the suggestions that klebsiella organisms have a key role in the pathogenesis of ankylosing spondylitis remains difficult to support until the original observations are independently confirmed.

\section{References}

1 Brewerton D A, Caffrey M, Hart F D, James D C O, Nicholls A, Sturrock R D. Ankylosing spondylitis and HL-A27. Lancet 1973; i: 904-7.

2 Woodrow J C. Histocompatibility antigens and rheumatic diseases. Semin Arthritis Rheum 1977; 6: 257-76.

3 Sairanen E, Tiilikainen A. HL-A27 in Reiter's disease following shigellosis. Scand J Rheumatol 1979; (suppl 8): Abstr 30-11.

4 Calin A, Fries J F. An 'experimental' epidemic of Reiter's syndrome revisited. Ann Intern Med 1976; 84: 564-6.

5 Aho K, Ahvonen P, Alkio P, et al. HL-A27 in reactive arthritis following infection. Ann Rheum Dis 1975; 34 (suppl 1): 29-30.

6 Hakansson U, Eitrem R, Low B, Winbald S. HLA antigen B27 in cases of joint affections in an outbreak of salmonellosis. Scand J Infect Dis 1976; 8: 245-8.

7 McDevitt H O, Bodmer W F. HL-A, immune-response genes, and disease. Lancet 1974; i: 1269-74.

8 Ebringer A. The cross-tolerance hypothesis, HLA-B27 and ankylosing spondylitis. Br J Rheumatol 1983; 22 (suppl 2): 53-66.

9 Ebringer R W, Cawdell D R, Cowling P, Ebringer A. Sequential studies in ankylosing spondylitis: association of Klebsiella pneumoniae and active disease. Ann Rheum Dis 1978; 37: $146-51$.

10 Avakian H, Welsh J, Ebringer A, Entwistle C C. Ankylosing spondylitis, HLA-B27 and Klebsiella. II. Cross-reactivity studies with human tissue typing sera. BrJ Exp Pathol 1980; 61: 92-6.

11 Welsh J, Avakian H, Cowling P, et al. Ankylosing spondylitis, HLA-B27 and Klebsiella. I. Cross-reactivity studies with rabbit antisera. Br J Exp Pathol 1980; 61: 85-91.

12 Seager K, Bashir H V, Geczy A F, Edmonds J, De VereTyndall A. Evidence for a specific B27-associated cell-surface marker on lymphocytes of patients with ankylosing spondylitis. Nature 1979; 277: 68-70.

13 Geczy A F, Seager K, Bashir H V, De Vere-Tyndall A, Edmonds $\mathrm{J}$. The role of Klebsiella in the pathogenesis of ankylosing spondylitis. II. Evidence for a specific B27associated marker on the lymphocytes of patients with ankylosing spondylitis. J Clin Lab Immunol 1980; 3: 23-8.

14 Edmonds J, Macauley D, Tyndall A, et al. Lymphocytotoxicity of anti-Klebsiella antisera in ankylosing spondylitis and related arthropathies. Patient and family studies. Arthritis Rheum 1981; 24: 1-7.

15 Geczy A F, Alexander K, Bashir H V, Edmonds J. A factor(s) in Klebsiella culture filtrates specifically modifies an HLA-B27associated cell-surface component. Nature 1980; 283: 782-4

16 Geczy A F, Alexander K, Bashir H V, Edmonds J P, Upfold L I, Sullivan J. HLA-B27, Klebsiella and ankylosing spondylitis: biological and chemical studies. Immunol Rev 1983; 70: 23-50.

17 Bennett P H, Wood P H N. Population studies of the rheumatic diseases. In: Bennett P H, Wood P N H, eds. Proceedings of the Third International Symposium. New York: Excerpta Medica, 1966: 456-78.

18 Terasaki P I, McClelland J D. Microdroplet assay of human serum cytotoxins. Nature 1964; 204: 998-1000.

19 Crowder J G, White A. A serologic response in human pseudomonas infection. $J$ Lab Clin Med 1970; 75: 128-36.

20 Armitage P. Statistical methods in medical research. Oxford: Blackwell Scientific, 1971.

21 Archer J R. Search for cross-reactivity between HLA B27 and Klebsiella pneumoniae. Ann Rheum Dis 1981; 40: 400-3.

22 Shinebaum R, Cooke E M, Siegerstetter J, Wright V. Effect of Klebsiella capsular antisera on lymphocytes from patients with ankylosing spondylitis. J Med Microbiol 1981; 14: 451-6.

23 Kinsella T D, Miller J, Lewkonia R M, Fritzler M J. Lack of molecular mimicry to Klebsiella in ankylosing spondylitis. N Arthritis Rheum 1981; 24: 78.

24 Kinsella T D, Lanteigne C, Fritzler M J, Lewkonia R M. Studies of lymphocytotoxicity by Klebsiella antisera in ankylosing spondylitis. Arthritis Rheum 1982; 25: 563.

25 Beaulieu A D, Rousseau F, Israel-Assayag E, Roy R. Klebsiella related antigens in ankylosing spondylitis. J Rheumatol 1983; 10: 102-5.

26 Heidelberger M, Dutton G S, Eriksen J, Nimmich W, Stirm S. Additional correlations of chemical structure and immunological specificity among cross-reactions of pneumococci and Klebsiella. Acta Pathol Microbiol Immunol Scand [C] 1982; 90: 87-90.

27 Geczy A F, Yap J. A survey of isolates of Klebsiella pneumoniae which cross-react with HLA-B27-associated cellsurface structure on the lymphocytes of patients with ankylosing spondylitis. J Rheumatol 1982; 9: 97-100. 
28 Edmonds J, Geczy A F, Sullivan J S, Prendergast J K, Upfold L I, Bashir H V. Enteric bacteria and HLA-B27 associated cell surface modification in patients with seronegative spondarthritis. Br J Rheumatol 1983; 22 (suppl 2): 75-82.

29 Geczy A F, Yap J. HLA-B27, Klebsiella and ankylosing spondylitis. Lancet 1979 ; i: $719-20$.

30 Prendergast J K, Sullivan J S, Geczy A, et al. Possible role of enteric organisms in the pathogenesis of ankylosing spondylitis and other seronegative arthropathies. Infect Immun 1983; 41: 935-41.

31 Georgopoulos K, Dirk W C, Goodacre J A, Pain R H. A reinvestigation of the cross-reactivity between Klebsiella and HLA-B27 in the aetiology of ankylosing spondylitis. Clin Exp Immunol (in press). 